\title{
Zawód pielęgniarki jako profesja szczególnie obciążona długotrwałym stresem i zagrożeniem wystąpienia depresji
}

\section{The profession of a nurse as a particularly burdened by long-term stress and the risk of depression}

\author{
MARIOLA RYBKA ${ }^{1}$ AGNIESZKA RYMAR $^{2}$ \\ ${ }^{1}$ Instytut Nauk o Zdrowiu, PUZ we Włocławku, Szpital Lipno Sp. z o.o. Zakład Opiekuńczo- \\ Leczniczy \\ ${ }^{2}$ Wojewódzki Szpital Zespolony im. Ludwika Rydygiera w Toruniu \\ DOI: http://dx.doi.org/10.21784/IwP.2020.001 \\ ISSN: 2451-1846
}

\section{Streszczenie:}

Wstęp. Odpowiedzialność wynikająca z wymagań stawianych w pielęgniarstwie sprawia, że wiele pielęgniarek i pielęgniarzy każdego dnia odczuwa presję i dyskomfort psychiczny. Mnogość, natężenie i częstotliwość czynników stresogennych doświadczanych każdego dnia pracy przez pielęgniarki i pielęgniarzy nieuchronnie prowadzą do wzrostu emocji negatywnych. W wielu badaniach udowodniono bezpośredni wpływ długotrwale doświadczanego przez pielęgniarki stresu na pogorszenie jakości życia na różnych jego płaszczyznach. Takie wielowymiarowe zaburzenie w pełnieniu ról życiowych prowadzi do wystąpienia objawów depresji, a tym samym do pogorszenia własnego dobrostanu zarówno psychicznego, jak i fizycznego.

Cel. Celem pracy było określenie stopnia obciążenia stresem osób wykonujących zawód pielęgniarki/pielęgniarza jak również uzyskanie odpowiedzi na pytanie czy pielęgniarstwo jako zawód szczególnie jest narażone na występowanie depresji. 
Materiał i metody. Grupę respondentów stanowiło 100 pielęgniarek pracujących w zróżnicowanych formach zatrudnienia w Szpital Lipno Sp. Z o.o. Do przeprowadzenia badań wykorzystano kwestionariusz ankiety konstrukcji własnej oraz test Becka BDI-II oraz psychologiczny pomiaru dyspozycyjnego radzenia sobie MINI COPE.

Wyniki. Uzyskane wyniki potwierdziły, że pielęgniarstwo jest zawodem szczególnie narażonym na długotrwały stres. 80\% ankietowanych pielęgniarek/rzy wykazuje duże narażenie na stres, $16 \%$ badanych niezbyt duże, a $4 \%$ znikome. Oznacza to, iż osiem na dziesięć pielęgniarek/pielęgniarzy odczuwa duże obciążenie stresem w swoim miejscu pracy. Objawy depresji występują u ponad 1/3 badanych (34\%).

Wnioski. Pielęgniarstwo jest zawodem szczególnie obciążone długotrwałym stresem, a co za tym idzie co trzecia pielęgniarka wskazuje na występowanie objawów depresji.

Słowa kluczowe: pielęgniarstwo, obciążenie, czynniki wywołujące długotrwały stres, objawy depresyjne

\section{Summary:}

Introduction.The responsibility arising from the requirements of nursing is causing that many nurses feel pressure and discomfort every day. The multitude, intensity and frequency of stressors experienced every day by nurses inevitably lead to an increase in negative emotions. Many studies have proven the direct impact of stress experienced by nurses on the deterioration of the quality of life on its various areas. Such a multidimensional disorder in performing life roles leads to symptoms of depression, and thus to deterioration of both mental and physical well-being. Aim. The aim of the presented research was to determine the degree of stress burden on people working as a nurse and to answer the question whether nursing as a profession is particularly prone to depression.

Material and methods. The group of respondents consisted of 100 nurses working in various forms of employment at Szpital Lipno Sp. z o.o. The study used a self-designed questionnaire, Beck's BDI-II test and the psychological measurement of disposable coping MINI COPE. 
Results. The obtained results confirmed that nursing is a profession particularly exposed to long-term stress. $80 \%$ of the surveyed nurses show a high exposure to stress, $16 \%$ of the respondents not too much, and $4 \%$ negligible. This means that eight out of ten nurses experience a high stress load in their workplace. Symptoms of depression occur in over $1 / 3$ of respondents (34\%).

Conclusions. Nursing is a profession that is particularly burdened with longterm stress, and thus every third nurse indicates symptoms of depression.

Key words: nursing, burden, stress factors, long-term stress, depressive symptoms

\section{Wstęp}

Pielęgniarstwo jako profesja obarczone jest dużą odpowiedzialnością tak pod względem zdrowia jak i bezpieczeństwa, zarówno własnego jak i pacjenta. Odpowiedzialność ta dla wielu pielęgniarek jest źródłem presji, która bezpośrednio wpływa na rozwój stresu. W tej pracy ogromną rolę odgrywa nie tylko konieczność sprawowania kompleksowej i profesjonalnej opieki nad pacjentami $\mathrm{w}$ różnym stanie, ale także stałe ryzyko pogorszenia własnego dobrostanu zarówno psychicznego jak i fizycznego. Mnogość, natężenie i częstotliwość czynników stresogennych doświadczanych na co dzień przez pielęgniarki nieuchronnie prowadzą do wzrostu emocji negatywnych. Wiele dotychczasowych badań dowodzi, że niepokój, gniew czy agresja u osób wysoko uspołecznionych są najczęściej tłumione i kierowane do wewnątrz, co $\mathrm{w}$ połączeniu $\mathrm{z}$ lękiem staje się podłożem rozwoju depresji i somatyzacji [1].

Statystyki są alarmujące. Niezależne badania prowadzone na przestrzeni ostatniego dziesięciolecia $\mathrm{w}$ różnych zakątkach świata zgodnie wykazują częstość występowania objawów depresyjnych na poziomie $30 \%$ i więcej $\mathrm{w}$ porównaniu do łącznych przypadków 
w danej populacji. Ponadto wyniki badań nad obciążeniem psychicznym w pielęgniarstwie ujawniają, że objawy lękowe pojawiały się z częstością występowania ponad $40 \%$, co daje wynik ponad 4-krotnie przekraczający średnie wartości w stosunku do wyniku ogółu [2].

Pielęgniarki doświadczające piętna depresji i stresu mogą mieć trudności nie tylko z pełnieniem funkcji zawodowych, ale także z funkcjonowaniem na innych płaszczyznach życia. Artykuł niniejszy opisuje jedynie skromny wycinek złożonego problemu, jakim jest szczególne obciążenie stresem w pielęgniarstwie oraz jego możliwe negatywne konsekwencje, wśród których depresja stanowi jedną z najbardziej dotkliwych. Obszerność i mnogość zagadnień w tym temacie przekracza możliwości tej publikacji, niemniej otwiera pole do dalszych analiz i poszukiwań rozwiązań opisanego problemu.

\section{Cel pracy}

Celem pracy było określenie stopnia obciążenia stresem osób wykonujących zawód pielęgniarki/pielęgniarza, jak również uzyskanie odpowiedzi na pytanie czy pielęgniarstwo jako zawód szczególnie jest narażone na występowanie depresji.

\section{Materiał i metody}

W pracy wykorzystano metodę sondażu diagnostycznego. Technikami badawczymi, jakimi posłużono się dla potrzeb procesu badawczego były: ankietowanie oraz technika skali szacunkowej. Narzędzia użyte w pracy to: autorski kwestionariusz ankiety własnej, Formularz Badania Objawów Depresji Becka BDI-II oraz Test Psychologiczny Pomiaru Dyspozycyjnego Radzenia Sobie MINI COPE.

Badanie zostało przeprowadzone z zachowaniem całkowitej anonimowości w NZOZ Szpital Lipno Sp. z o.o. Sondaż diagnostyczny objął 100 pełnoletnich respondentów, którzy w różnej formie 
i różnym wymiarze godzin pozostają zatrudnieni w charakterze pielęgniarki/pielęgniarza $\mathrm{w}$ wyżej wymienionej jednostce ochrony zdrowia oraz posiadają wykształcenie $\mathrm{z}$ zakresu pielęgniarstwa. Otrzymane kwestionariusze każda osoba badana wypełniała dobrowolnie, samodzielnie oraz bez narzuconych ograniczeń czasowych. Uzyskane wyniki badań poddano analizie statystycznej testem $\chi^{2}$ dla prób niezależnych. Przyjęto 5\% ryzyko błędu wnioskowania. Wartość prawdopodobieństwa $\mathrm{p}<0,05$ uznano za statystycznie istotną. Do zbadania zależności statystycznej pomiędzy analizowanymi cechami użyto testu Chi - kwadrat.

\section{Wyniki}

Prezentowane poniżej badania, miały na celu określenie szczególnego obciążenia stresem osób wykonujących zawód pielęgniarki/pielęgniarza jak również uzyskanie odpowiedzi na pytanie czy pielęgniarstwo jako zawód jest szczególnie obciążone występowaniem objawów depresyjnych. Ponadto podjęto próbę określenia wpływu długości stażu pracy pielęgniarek/pielęgniarzy na częstość występowania objawów depresji. 
Tab. I. Miejsce pracy a narażenie na stres.

\begin{tabular}{|c|c|c|c|c|c|c|c|c|}
\hline & & & \multicolumn{3}{|c|}{ NARAŻENIE NA STRES } & \multirow[b]{2}{*}{ Ogółem } & \multirow{2}{*}{$\begin{array}{c}\text { Chi- } \\
\text { kwadrat } \\
\text { Pearson } \\
\text { a } \\
\end{array}$} & \multirow[b]{2}{*}{$\mathrm{P}$} \\
\hline & & & duże & $\begin{array}{l}\text { niezbyt } \\
\text { duże }\end{array}$ & znikome & & & \\
\hline \multirow{12}{*}{$\begin{array}{l}\text { MIEJSC } \\
\text { E } \\
\text { PRACY }\end{array}$} & \multirow{2}{*}{$\begin{array}{c}\text { Ośrodek Terapii } \\
\text { Uzależnień/placówk } \\
\text { a oświaty }\end{array}$} & $\mathrm{n}$ & 1 & 0 & 0 & 1 & \multirow{14}{*}{35,43} & \multirow{14}{*}{$\begin{array}{c}0,000 \\
1\end{array}$} \\
\hline & & $\%$ & $\begin{array}{c}100,0 \\
\%\end{array}$ & $0,0 \%$ & $0,0 \%$ & $100,0 \%$ & & \\
\hline & \multirow[b]{2}{*}{ placówka oświaty } & $\mathrm{n}$ & 0 & 0 & 1 & 1 & & \\
\hline & & $\%$ & $0,0 \%$ & $0,0 \%$ & $\begin{array}{c}100,0 \\
\%\end{array}$ & $100,0 \%$ & & \\
\hline & \multirow{2}{*}{$\begin{array}{l}\text { przychodnia } \\
\text { POZ/specjalist. }\end{array}$} & $\mathrm{n}$ & 7 & 3 & 0 & 10 & & \\
\hline & & $\%$ & $70,0 \%$ & $30,0 \%$ & $0,0 \%$ & $100,0 \%$ & & \\
\hline & \multirow{2}{*}{ szpital/klinika } & $\mathrm{n}$ & 58 & 7 & 2 & 67 & & \\
\hline & & $\%$ & $86,6 \%$ & $10,4 \%$ & $3,0 \%$ & $100,0 \%$ & & \\
\hline & \multirow{2}{*}{ uzdrowisko } & $\mathrm{n}$ & 4 & 4 & 1 & 9 & & \\
\hline & & $\%$ & $44,4 \%$ & $44,4 \%$ & $11,1 \%$ & $100,0 \%$ & & \\
\hline & \multirow{2}{*}{$\begin{array}{l}\text { Zakł. Opiekuńczo- } \\
\text { Leczniczy/Dom } \\
\text { Opieki Spol. } \\
\text { Hospicjum }\end{array}$} & $\mathrm{n}$ & 10 & 2 & 0 & 12 & & \\
\hline & & $\%$ & $83,3 \%$ & $16,7 \%$ & $0,0 \%$ & $100,0 \%$ & & \\
\hline & \multirow{2}{*}{ Ogółem } & $\begin{array}{l}\text { n } \\
*\end{array}$ & 80 & 16 & 4 & 100 & & \\
\hline & & $\%$ & $80,0 \%$ & $\begin{array}{r}16,0 \\
\%\end{array}$ & $4,0 \%$ & $\begin{array}{r}100,0 \\
\% \\
\end{array}$ & & \\
\hline
\end{tabular}

Uzyskane na podstawie ankiety własnej oraz formularza BDIII rezultaty badań potwierdziły postawioną hipotezę, że pielęgniarstwo jest zawodem szczególnie obciążonym długotrwałym stresem. Analiza statystyczna wykazała istotną zależność pomiędzy miejscem pracy ankietowanych a ich opinią, jak bardzo są narażeni na stres $\mathrm{w}$ pracy. Ponad $86 \%$ badanych pracujących w szpitalu/klinice twierdzi, iż natężenie stresu w pracy jest duże. Natomiast ponad 44\% badanych, których głównym miejscem zatrudnienia jest uzdrowisko twierdzi, że natężenie stresu jest niezbyt duże. 
Tab. II. Częstość występowania sytuacji stresowych w miejscu pracy.

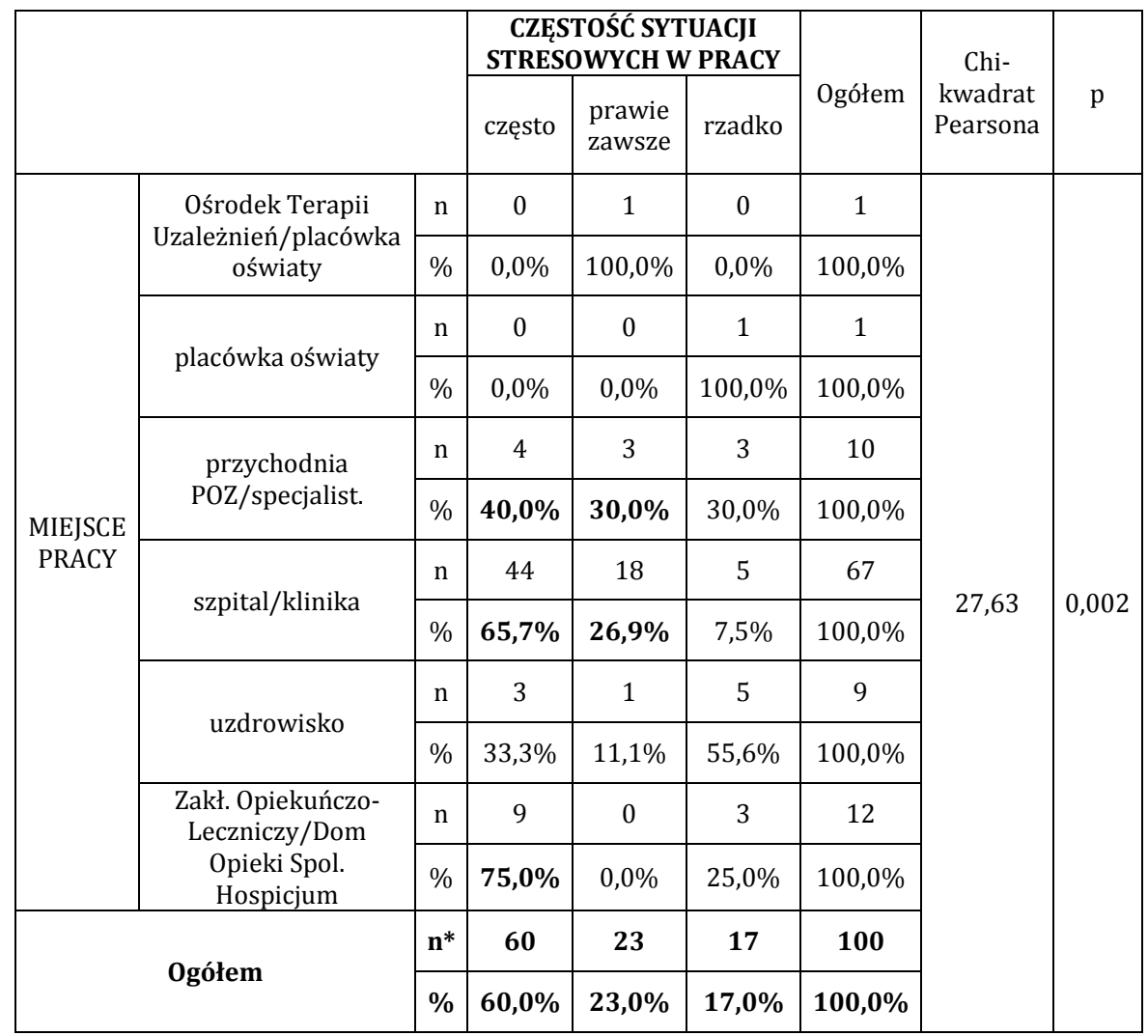

Ponadto, kolejna analiza statystyczna wykazała istotną zależność pomiędzy miejscem pracy ankietowanych a tym, jak często są narażeni na sytuacje stresujące w pracy. Ponad 65\% badanych pracujących w szpitalu przyznaje, iż często spotyka się z sytuacjami stresowymi w pracy. Natomiast ponad 55\% badanych zatrudnionych głównie w uzdrowisku przyznaje, że rzadko spotykają ich sytuację stresowe w pracy. 
Kolejne wyniki wykazały istotną zależność pomiędzy stażem pracy ankietowanych a ich opinią jak bardzo są narażeni na stres w pracy. W każdej badanej grupie wiekowej ponad połowa ankietowanych klasyfikuje odczuwane narażenie na stres jako „duże”.

Tab. III. Staż pracy a odczuwane narażenie na stres.

\begin{tabular}{|c|c|c|c|c|c|c|c|c|}
\hline & \multicolumn{3}{|c|}{$\begin{array}{c}\text { ODCZUWANIE } \\
\text { NARAŻENIA NA STRES }\end{array}$} & \multirow{2}{*}{ Ogółem } & \multirow{2}{*}{$\begin{array}{c}\text { Chi- } \\
\text { kwadrat } \\
\text { Pearsona }\end{array}$} & \multirow{2}{*}{$\mathrm{P}$} \\
\hline & & & duże & $\begin{array}{l}\text { niezbyt } \\
\text { duże }\end{array}$ & znikome & & & \\
\hline \multirow{8}{*}{$\begin{array}{c}\text { STAŻ } \\
\text { PRACY } \\
\text { W } \\
\text { LATACH }\end{array}$} & \multirow{2}{*}{$11-20$} & $\mathrm{n}$ & 9 & 7 & 0 & 16 & \multirow{10}{*}{17,12} & \multirow{10}{*}{0,009} \\
\hline & & $\%$ & $56,3 \%$ & $43,8 \%$ & $0,0 \%$ & $100,0 \%$ & & \\
\hline & \multirow{2}{*}{$21-30$} & $\mathrm{n}$ & 29 & 1 & 0 & 30 & & \\
\hline & & $\%$ & $96,7 \%$ & $3,3 \%$ & $0,0 \%$ & $100,0 \%$ & & \\
\hline & \multirow{2}{*}{$\begin{array}{l}\text { mniej } \\
\text { niż } 10\end{array}$} & $\mathrm{n}$ & 23 & 3 & 2 & 28 & & \\
\hline & & $\%$ & $82,1 \%$ & $10,7 \%$ & $7,1 \%$ & $100,0 \%$ & & \\
\hline & \multirow{2}{*}{$\begin{array}{c}\text { ponad } \\
30\end{array}$} & $\mathrm{n}$ & 19 & 5 & 2 & 26 & & \\
\hline & & $\%$ & $73,1 \%$ & $19,2 \%$ & $7,7 \%$ & $100,0 \%$ & & \\
\hline \multirow{2}{*}{\multicolumn{2}{|c|}{ Ogółem }} & $\mathbf{n}^{*}$ & 80 & 16 & 4 & 100 & & \\
\hline & & $\%$ & $80,0 \%$ & $16,0 \%$ & $4,0 \%$ & $100,0 \%$ & & \\
\hline
\end{tabular}

Dalsza analiza statystyczna wykazała związek pomiędzy występowaniem objawów depresji a narażeniem na stres $\mathrm{w}$ miejscu pracy, co potwierdza założenia drugiej hipotezy. U 21,3\% ankietowanych, którzy wskazali duże narażenie na stres wystąpił epizod depresyjny o łagodnym nasileniu, u kolejnych 5\% miał on nasilenie umiarkowane. Odpowiedzi $12,5 \%$ ankietowanych wykazały epizod depresyjny o głębokim nasileniu, natomiast 61,3\% nie wykazało objawów depresji. 
Tab. IV. Występowanie objawów depresyjnych a narażenie na stres.

\begin{tabular}{|c|c|c|c|c|c|c|c|c|c|}
\hline & & & \multicolumn{4}{|c|}{ POZIOM DEPRESJI } & \multirow[b]{2}{*}{ Ogółem } & \multirow[b]{2}{*}{$\begin{array}{l}\text { Chi- } \\
\text { kwa } \\
\text { drat } \\
\text { Pear } \\
\text { sona }\end{array}$} & \multirow[b]{2}{*}{$\mathrm{P}$} \\
\hline & & & $\begin{array}{c}\text { brak } \\
\text { depre } \\
\text { sji }\end{array}$ & $\begin{array}{c}\text { epizod } \\
\text { depresy } \\
\text { jny o } \\
\text { głęboki } \\
\text { m } \\
\text { nasileni } \\
\text { u }\end{array}$ & $\begin{array}{c}\text { epizod } \\
\text { depresy } \\
\text { jny o } \\
\text { łagodny } \\
\text { m } \\
\text { nasileni } \\
\text { u }\end{array}$ & $\begin{array}{c}\text { epizod } \\
\text { depresyj } \\
\text { ny o } \\
\text { umiarko } \\
\text { wanym } \\
\text { nasileniu }\end{array}$ & & & \\
\hline \multirow{6}{*}{$\begin{array}{c}\text { NARAŻE } \\
\text { NIE NA } \\
\text { STRES }\end{array}$} & \multirow{2}{*}{ duże } & $\mathrm{n}$ & 49 & 10 & 17 & 4 & 80 & \multirow{8}{*}{5,91} & \multirow{8}{*}{0,0433} \\
\hline & & $\%$ & $61,3 \%$ & $12,5 \%$ & $21,3 \%$ & $5,0 \%$ & $100,0 \%$ & & \\
\hline & \multirow{2}{*}{$\begin{array}{c}\text { niezb } \\
\text { yt } \\
\text { duże } \\
\end{array}$} & $\mathrm{n}$ & 13 & 0 & 3 & 0 & 16 & & \\
\hline & & $\%$ & $81,3 \%$ & $0,0 \%$ & $18,8 \%$ & $0,0 \%$ & $100,0 \%$ & & \\
\hline & \multirow{2}{*}{$\begin{array}{c}\text { zniko } \\
\text { me }\end{array}$} & $\mathrm{n}$ & 4 & 0 & 0 & 0 & 4 & & \\
\hline & & $\%$ & $\begin{array}{c}100,0 \\
\% \\
\end{array}$ & $0,0 \%$ & $0,0 \%$ & $0,0 \%$ & $100,0 \%$ & & \\
\hline \multirow{2}{*}{\multicolumn{2}{|c|}{ Ogółem }} & $\mathbf{n}$ & 66 & 10 & 20 & 4 & 100 & & \\
\hline & & $\%$ & $\begin{array}{c}66,0 \\
\%\end{array}$ & $10,0 \%$ & $20,0 \%$ & $4,0 \%$ & $100,0 \%$ & & \\
\hline
\end{tabular}

Ponadto wykazano istotną zależność pomiędzy częstością występowania sytuacji stresowych w miejscu pracy a wystąpieniem objawów depresyjnych. U 26,7\% ankietowanych, którzy wskazali odpowiedź „często” wystąpił epizod depresyjny o łagodnym nasileniu, u kolejnych 6,7\% miał on nasilenie umiarkowane. Odpowiedzi 3,3\% ankietowanych wykazały epizod depresyjny o głębokim nasileniu, natomiast $63,3 \%$ nie wykazało objawów depresji. 
Tab. V. Częstość doświadczania sytuacji stresowych w pracy a występowanie objawów depresyjnych.

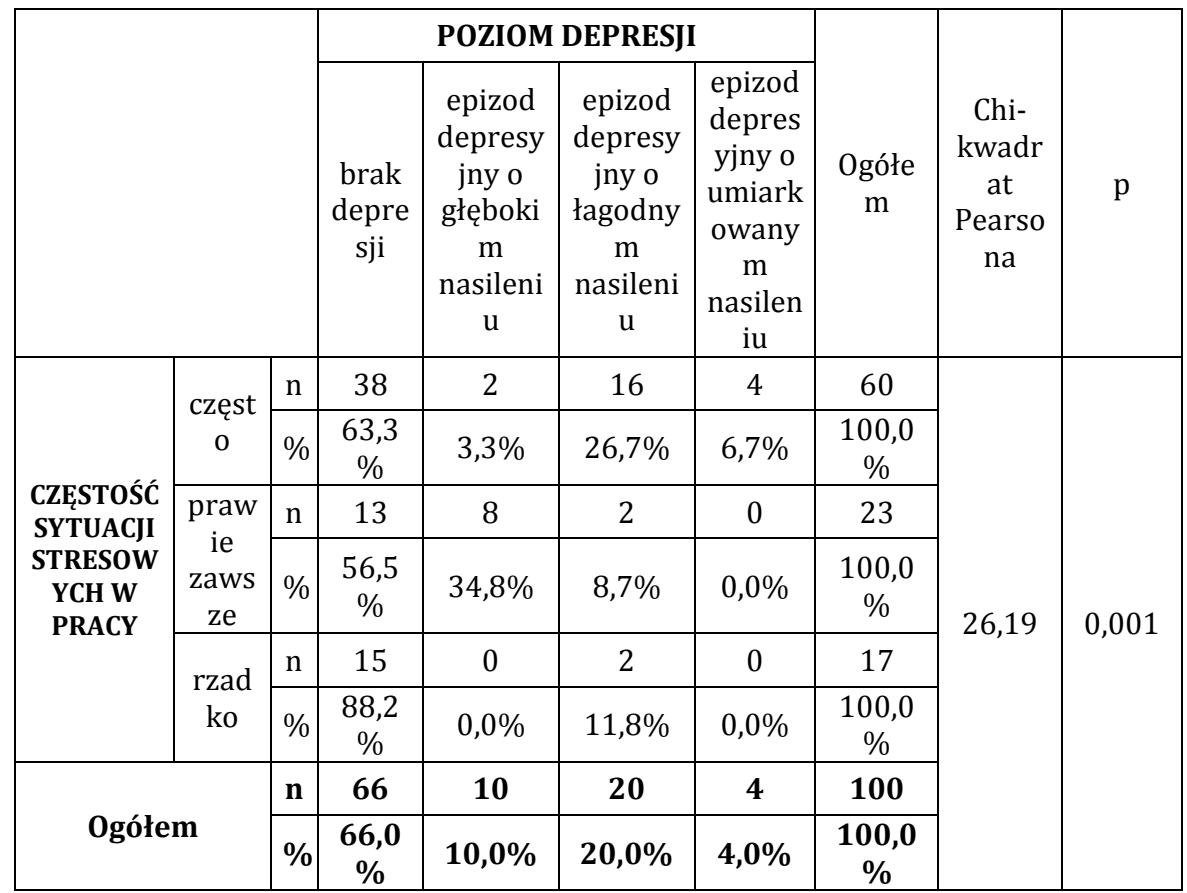

W tym miejscu należy zauważyć, iż u $40 \%$ ankietowanych, którzy bardzo często odczuwają negatywne emocje w czasie pracy wystąpił epizod depresyjny o głębokim nasileniu, natomiast $60 \%$ badanych nie wykazało objawów depresji. Nie da się jednakże nie zauważyć, że ogółem $32 \%$ badanych odczuwających negatywne emocje w czasie pracy doświadczyło epizodu depresyjnego o różnym stopniu nasilenia. 
Tab. VI. Odczuwanie negatywnych emocji w pracy a występowanie objawów depresyjnych.

\begin{tabular}{|c|c|c|c|c|c|c|c|c|c|}
\hline & & & \multicolumn{4}{|c|}{ POZIOM DEPRESJI } & \multirow[b]{2}{*}{ Ogółem } & \multirow[b]{2}{*}{$\begin{array}{l}\text { Chi- } \\
\text { kwa } \\
\text { drat } \\
\text { Pear } \\
\text { sona }\end{array}$} & \multirow[b]{2}{*}{$\mathrm{P}$} \\
\hline & & & $\begin{array}{c}\text { brak } \\
\text { depre } \\
\text { sji }\end{array}$ & $\begin{array}{c}\text { epizod } \\
\text { depresy } \\
\text { jny o } \\
\text { głęboki } \\
\text { m } \\
\text { nasileni } \\
\text { u }\end{array}$ & $\begin{array}{c}\text { epizod } \\
\text { depresy } \\
\text { jny o } \\
\text { łagodny } \\
\text { m } \\
\text { nasileni } \\
\text { u }\end{array}$ & $\begin{array}{c}\text { epizod } \\
\text { depresyj } \\
\text { ny o } \\
\text { umiarko } \\
\text { wanym } \\
\text { nasileniu }\end{array}$ & & & \\
\hline \multirow{10}{*}{$\begin{array}{c}\text { ODCZUWA } \\
\text { NIE } \\
\text { NEGATYW } \\
\text { NYCH } \\
\text { EMOCJI W } \\
\text { CZASIE } \\
\text { PRACY }\end{array}$} & \multirow{2}{*}{$\begin{array}{c}\text { bard } \\
\text { zo } \\
\text { częst } \\
\text { o } \\
\end{array}$} & $\mathrm{n}$ & 3 & 2 & 0 & 0 & 5 & \multirow{12}{*}{18,25} & \multirow{12}{*}{0,108} \\
\hline & & $\%$ & $60,0 \%$ & $40,0 \%$ & $0,0 \%$ & $0,0 \%$ & $100,0 \%$ & & \\
\hline & \multirow{2}{*}{$\begin{array}{c}\text { dość } \\
\text { częst } \\
0\end{array}$} & $\mathrm{n}$ & 26 & 8 & 12 & 1 & 47 & & \\
\hline & & $\%$ & $55,3 \%$ & $17,0 \%$ & $25,5 \%$ & $2,1 \%$ & $100,0 \%$ & & \\
\hline & \multirow{2}{*}{$\begin{array}{c}\text { nie } \\
\text { dotyc } \\
\text { zy }\end{array}$} & $\mathrm{n}$ & 8 & 0 & 2 & 0 & 10 & & \\
\hline & & $\%$ & $80,0 \%$ & $0,0 \%$ & $20,0 \%$ & $0,0 \%$ & $100,0 \%$ & & \\
\hline & \multirow{2}{*}{$\begin{array}{c}\text { rzadk } \\
0\end{array}$} & $\mathrm{n}$ & 28 & 0 & 6 & 3 & 37 & & \\
\hline & & $\%$ & $75,7 \%$ & $0,0 \%$ & $16,2 \%$ & $8,1 \%$ & $100,0 \%$ & & \\
\hline & \multirow{2}{*}{$\begin{array}{c}\text { w } \\
\text { ogóle }\end{array}$} & $\mathrm{n}$ & 1 & 0 & 0 & 0 & 1 & & \\
\hline & & $\%$ & $\begin{array}{c}100,0 \\
\%\end{array}$ & $0,0 \%$ & $0,0 \%$ & $0,0 \%$ & $100,0 \%$ & & \\
\hline \multirow{2}{*}{\multicolumn{2}{|c|}{ Ogółem }} & $\mathbf{n}$ & 66 & 10 & 20 & 4 & 100 & & \\
\hline & & $\%$ & $\begin{array}{c}66,0 \\
\%\end{array}$ & $10,0 \%$ & $20,0 \%$ & $4,0 \%$ & $100,0 \%$ & & \\
\hline
\end{tabular}

Ostatnia przeprowadzona analiza statystyczna wykazała istotną zależność pomiędzy stażem pracy ankietowanych a ich poziomem depresji, co jednocześnie potwierdziło trzecią z postawionych hipotez; $50 \%$ badanych ze stażem pracy ponad 30 lat wykazuje brak depresji. Natomiast pozostałe 50\% ankietowanych pracujących w zawodzie ponad 30 lat wykazuje epizody depresyjne o różnym stopniu nasilenia. 
Tab. VII. Staż pracy a poziom depresji.

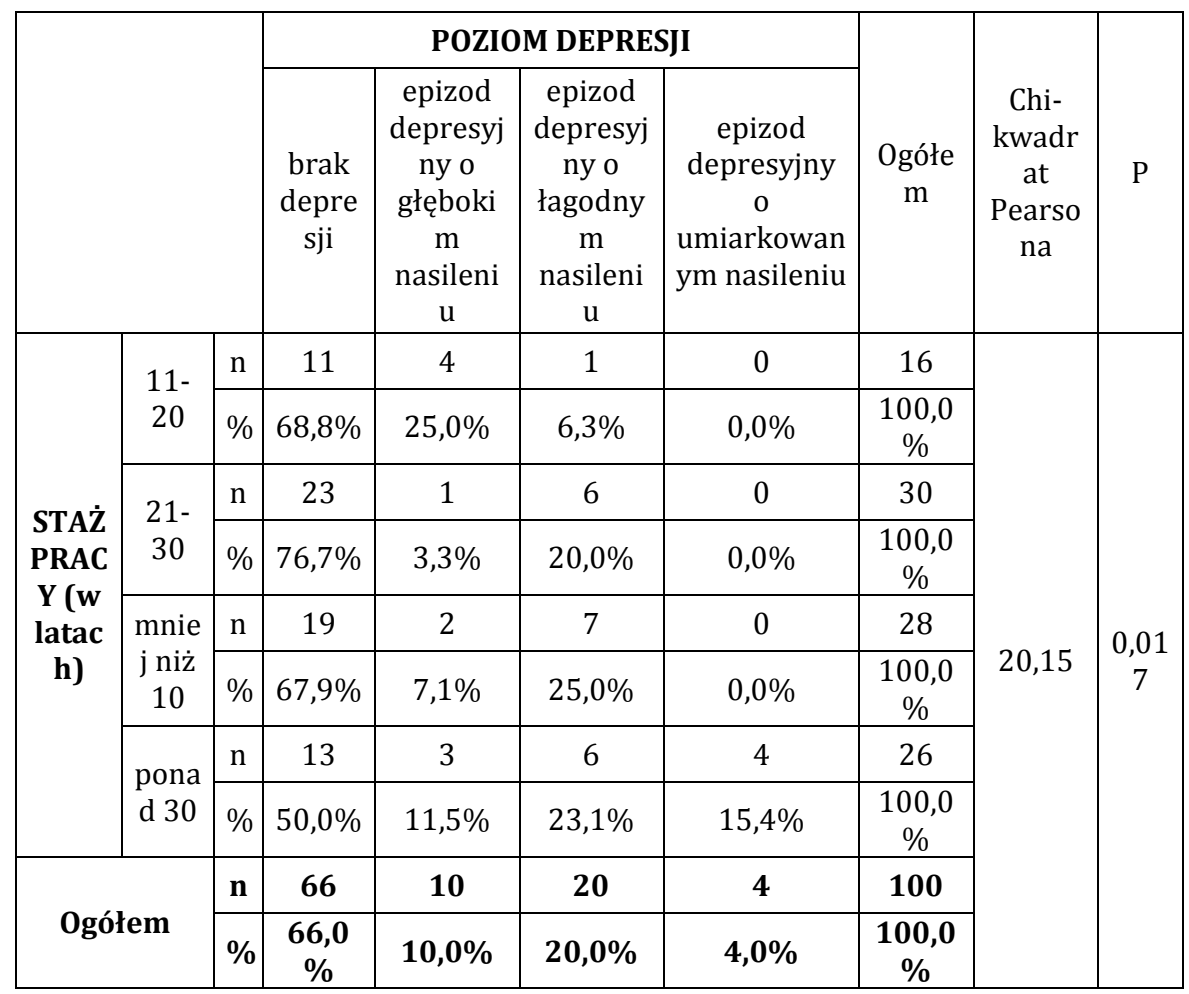

\section{Dyskusja}

Uzyskane na podstawie ankiety własnej rezultaty badań potwierdziły pierwszą postawioną hipotezę, że pielęgniarstwo jest zawodem szczególnie długotrwałym obciążonym stresem. W badanej grupie respondentów $80 \%$ ankietowanych pielęgniarek i pielęgniarzy wykazuje duże narażenie na stres, $16 \%$ badanych niezbyt duże, a $4 \%$ znikome. Oznacza to, iż osiem na dziesięć pielęgniarek/pielęgniarzy odczuwa duże obciążenie stresem $\mathrm{w}$ swoim miejscu pracy. $60 \%$ 
badanych przyznaje, iż często spotykają się z sytuacją stresową w pracy. $23 \%$ badanych odpowiada, że spotyka się z taką sytuacją prawie zawsze, a $17 \%$ respondentów rzadko doświadcza sytuacji stresowych w pracy.

Nawiązując do powyżej opisanych aspektów i analizując zjawisko stresu w zawodzie pielęgniarki w kontekście pierwszej postawionej hipotezy, należy mocno zaznaczyć jego długoterminowe oddziaływanie, przez co staje się on szczególnie dotkliwym, powtarzalnym i w oczywisty sposób negatywnym składnikiem nie tylko środowiska pracy ale także innych obszarów codziennego funkcjonowania. Duża powtarzalność w skali $60 \%$ (często) oraz $23 \%$ (prawie zawsze), ogromne natężenie wielkości 80\% oraz doświadczanie negatywnych emocji po zakończeniu pracy przez $61 \%$ ankietowanych dobitnie świadczą o przytłaczającej skali tego zjawiska oraz jego długoterminowości. Niemal identyczny wynik opisują w swojej pracy Roberts i wsp. przytoczone przez niego wyniki badań wskazują na szczególne narażenie wystąpienia skutków długotrwałego stresu, w tym somatyzacji u ponad $60 \%$ badanej grupy pielęgniarek [3].

Wyniki te korespondują $\mathrm{z}$ badaniami przeprowadzonymi przez Kędrę i Nowocień, w których potwierdziły one występowanie w pielęgniarstwie charakterystycznego stresu, którego czynniki są specyficzne dla tego zawodu - odpowiedzialność za życie i zdrowie oraz brak zrozumienia ze strony pacjentów i ich rodzin [4]. Podobne wyniki badań w swojej pracy nad stresem i wypaleniem zawodowym w pielęgniarstwie opisują Dąbrowska, Olejnik, Kułak - Bejda i Krajewska - Kułak, gdzie na podstawie przeanalizowanych badań i dostępnej literatury dowodzą, że personel pielęgniarski jest nieustannie narażony na przeżywanie stresu zawodowego [5].

Ponadto, analiza statystyczna wykazała istotną zależność pomiędzy miejscem pracy ankietowanych a ich opinią jak bardzo są 
narażeni na stres $\mathrm{w}$ pracy. Ponad $86 \%$ badanych pracujących w szpitalu/klinice twierdzi, iż natężenie stresu w pracy jest duże. Wynik wpisuje się $\mathrm{w}$ założenia koncepcji przedstawionej przez Maslach i Leiter, gdzie wskazują oni na organizację miejsca pracy oraz jej dysfunkcje jako główne źródła sytuacji stresowych wśród pracowników [6].

Dzięki przeprowadzonej analizie statystycznej wykazano istotną zależność pomiędzy stażem pracy ankietowanych a ich opinią jak bardzo są narażeni na stres w pracy. Ponad 96\% badanych ze stażem pracy 21-30 lat twierdzi iż natężenie stresu w pracy jest duże. Odpowiedzi te nie są zgodne ze stanowiskiem Kliszcz, która w swoim artykule wskazuje na badania pielęgniarek w grupie o średniej wieku 63 lata; osoby te były najbardziej podatne na podwyższony poziom stresu i związanego z nim lęku niezależnie od stażu pracy [7].

Niejako negatywnym podsumowaniem uzyskanych rezultatów $\mathrm{w}$ zakresie obciążenia stresem $\mathrm{w}$ pielęgniarstwie są odpowiedzi ankietowanych udzielone na pytanie o ponowny wybór zawodu; na 100 ankietowanych tylko 9 osób zdecydowanie wybrałoby ten zawód ponownie, 29 osób odpowiedziało „raczej tak”, natomiast pozostałe 62 osoby albo nie są w stanie skłonić się w żadną stronę (tak lub nie), albo nie zdecydowałyby się na wybór zawodu pielęgniarki/pielęgniarza ponownie.

W celu zweryfikowania postawionej hipotezy dotyczącej obciążenia występowaniem objawów depresji wśród osób pracujących $\mathrm{w}$ pielęgniarstwie, przeprowadzono badanie zależności pomiędzy miejscem pracy a występowaniem objawów depresji analiza statystyczna nie wykazała istotnej zależności pomiędzy miejscem pracy ankietowanych a ich poziomem depresji, niemniej należy zaznaczyć, że odpowiedzi 13 osób, których głównym miejscem zatrudnienia jest szpital lub klinika wskazują na epizod depresyjny 
o łagodnym nasileniu, 3 odpowiedzi wskazują na epizod o umiarkowanym charakterze, a 6 udzielonych odpowiedzi wskazało na epizod depresyjny o głębokim nasileniu. Oznacza to, że u 22 z 67 badanych, czyli u prawie 33\% osób zatrudnionych w szpitalu lub klinice wystąpiły objawy depresyjne.

Kolejną, badaną zależnością, był związek wieku ankietowanych i występowania u nich objawów depresji. Przeprowadzona analiza statystyczna nie wykazała istotnej zależności pomiędzy wiekiem ankietowanych a ich poziomem depresji. Niemniej jednak nie można zlekceważyć faktu, iż odpowiedzi 34 osób, (łącznie ze wszystkich grup wiekowych), wykazały wystąpienie epizodu depresyjnego o różnym nasileniu. Biorąc pod uwagę, iż liczebność całej grupy ankietowanych wynosiła 100, uzyskany wynik stanowi aż 34\% ogółu.

Również poddano analizie związek pomiędzy narażeniem na stres w miejscu pracy i występowaniem objawów depresji. Analiza statystyczna wykazała istnienie związku pomiędzy wymienionymi wyżej zmiennymi. U 21,3\% ankietowanych, którzy wskazali duże narażenie na stres wystąpił epizod depresyjny o łagodnym nasileniu, u kolejnych $5 \%$ miał on nasilenie umiarkowane. Odpowiedzi 12,5\% ankietowanych wykazały epizod depresyjny o głębokim nasileniu, natomiast $61,3 \%$ nie wykazało objawów depresji.

Następną badaną zależnością w zakresie weryfikacji drugiej hipotezy był związek występowania objawów depresyjnych a częstością narażenia na stres w miejscu pracy. Analiza statystyczna wykazała istotną zależność pomiędzy częstością występowania sytuacji stresowych w miejscu pracy a wystąpieniem objawów depresyjnych. W badanej grupie 100 osób, 34 odpowiedzi wskazują na wystąpienie epizodu depresyjnego (o różnym nasileniu).

Ostatni badany związek stanowiło odczuwanie negatywnych emocji a występowanie objawów depresyjnych. W tym przypadku 
u 40\% ankietowanych, którzy bardzo często odczuwają negatywne emocje w czasie pracy wystąpił epizod depresyjny o głębokim nasileniu, natomiast $60 \%$ badanych nie wykazało żadnych objawów depresji. Oznacza to, iż zależność tą cechuje największy odsetek obciążenia niż pozostałe badane na potrzeby drugiej hipotezy związki.

Wszystkie powyżej uzyskane wyniki wskazują, że nie mniej niż 30 \% badanej zbiorowości doświadcza lub doświadczyło epizodu depresyjnego o różnym nasileniu, którego źródło stanowił stres w pracy. Uzyskany wynik jest zaskakująco zgodny $\mathrm{z}$ badaniami własnymi Maharaj, Lees i Lal, które w badaniu kohortowym przeprowadzonym wśród australijskich pielęgniarek w 2017 roku wykazały rozpowszechnienie objawów depresyjnych na poziomie $32,4 \%$ badanej zbiorowości. Ponadto wskazują wiek, lata pracy i doświadczanie negatywnych emocji w związku z wykonywaną pracą jako mające znaczący wpływ na rozwój depresji wśród pielęgniarek [2]. Zależności pomiędzy miejscem zatrudnienia a występowaniem objawów depresji została również sprawdzone w pracy Letvak, Ruhm i McCoy, gdzie autorzy wykazali najsilniejsze obciążenie depresją wśród osób zatrudnionych w szpitalu. Ponadto badania te ujawniły silny wpływ objawów depresyjnych na subiektywne odczucie dobrostanu zarówno fizycznego jak i umysłowego pielęgniarek [8].

Kolejny badany związek to zależność pomiędzy narażeniem na stres w miejscu pracy a natężeniem objawów depresji - odpowiedzi 34\% badanych wykazały istnienie takiego związku, co częściowo koresponduje z wynikami uzyskanymi przez Da Silva Gherardi Donato i współpracowników, którzy w swoich badaniach taką zależność wykazali u 20\% ankietowanych, a na podstawie przeanalizowanej przez nich literatury przytaczają wartość 28,8\% [9].

Jako ostatnią hipotezę w niniejszej pracy przyjęto wpływ stażu pracy na częstość występowania objawów depresji. Przeprowadzona 
analiza statystyczna wykazała istotną zależność pomiędzy stażem pracy ankietowanych a ich poziomem depresji. 50\% badanych ze stażem pracy ponad 30 lat wykazuje brak depresji. Natomiast pozostałe $50 \%$ ankietowanych pracujących w zawodzie ponad 30 lat wykazuje epizody depresyjne o różnym stopniu nasilenia. Oznacza to, że połowa badanej zbiorowości pielęgniarek i pielęgniarzy zostaje dotknięta objawami depresji.

W zakresie badania powyższej zależności interesujące wyniki uzyskał zespół Haor, Głowackiej, Ślusarza i Piotrowskiej, który zauważył, że zadowolenie z życia wśród badanej grupy zmienia się w sposób odwrotnie proporcjonalny do stażu pracy; istotnie maleje wraz z rosnącą ilością przepracowanych lat i przybiera najniższe wartości wśród pielęgniarek, które przepracowały w zawodzie więcej niż 30 lat. Ponadto zauważają oni, że zwiększenie liczby czynników wywołujących stres wynikający $\mathrm{z}$ pełnienia funkcji zawodowych postępuje $\mathrm{w}$ miarę zaawansowania wieku i stażu pracy pielęgniarek. Równie ważną poczynioną obserwacją jest stwierdzenie, że im dłuższy staż pielęgniarek i pielęgniarzy tym większa skłonność do łatwego wycofywania się, godzenia $\mathrm{z}$ niepowodzeniami oraz rezygnacji z sukcesów [10].

Niejako uzupełniającym badaniem na potrzeby niniejszej pracy było wykorzystanie kwestionariusza MINI-COPE dla oceny radzenia sobie ze stresem i jego skutkami. Według udzielonych odpowiedzi badani wśród sposobów radzenia sobie ze stresem najczęściej wskazywali (wartości średnie): zajmowanie się czymś innym; średnio - 2,21, akceptację zaistniałego faktu; średnio - 2,02 oraz żartowanie na temat stresowej sytuacji - 1,99. W dalszej kolejności ankietowani wskazali obwinianie siebie - 1,94, aktywne radzenie sobie - 1,89 oraz poszukiwanie instrumentalnego wsparcia 1,85. Najmniej odpowiedzi skłaniało się w stronę używania substancji psychoaktywnych i alkoholu - 0,28 oraz zaprzeczania - 0,05. 
Tab. VIII. Wyniki badań uzyskane za pomocą formularza MINI-COPE.

\begin{tabular}{|c|c|c|c|c|}
\hline Nazwa skali & Twierdzenia & $\begin{array}{l}\text { Numery } \\
\text { pytań }\end{array}$ & $\begin{array}{c}\text { Śred } \\
\text { nia }\end{array}$ & SD \\
\hline Aktywne radzenie sobie & $\begin{array}{lr}\text { podejmowanie } & \text { działań } \\
\text { zmierzających do poprawienia } \\
\text { sytuacji }\end{array}$ & 2,7 & 1,89 & 0,22 \\
\hline Planowanie & $\begin{array}{l}\text { zastanawianie się i planowanie } \\
\text { tego co należy zrobić }\end{array}$ & 14,25 & 1,42 & 0,24 \\
\hline $\begin{array}{l}\text { Pozytywne } \\
\text { przewartościowanie }\end{array}$ & $\begin{array}{l}\text { spostrzeganie sytuacji w bardziej } \\
\text { pozytywnym świetle }\end{array}$ & 12,17 & 1,22 & 0,22 \\
\hline Akceptacja & $\begin{array}{l}\text { przyjęcie zaistniałej sytuacji i } \\
\text { uczenie się jak z tym żyć }\end{array}$ & 20,24 & 2,02 & 0,34 \\
\hline Poczucie humoru & $\begin{array}{l}\text { żartowanie i traktowanie sytuacji } \\
\text { jako zabawy }\end{array}$ & 18,28 & 1,99 & 1,20 \\
\hline Zwrot ku religii & $\begin{array}{l}\text { modlitwa. Medytowanie celem } \\
\text { znalezienia ukojenia }\end{array}$ & 22,27 & 1,15 & 0,52 \\
\hline $\begin{array}{ll}\begin{array}{l}\text { Poszukiwanie } \\
\text { emocjonalnego }\end{array} & \\
\end{array}$ & $\begin{array}{l}\text { szukanie otuchy, zrozumienia i } \\
\text { wsparcia od innych }\end{array}$ & 5,15 & 1,55 & 0,19 \\
\hline $\begin{array}{l}\text { Poszukiwanie wsparcia } \\
\text { instrumentalnego }\end{array}$ & $\begin{array}{l}\text { szukanie i otrzymywanie pomocy } \\
\text { od innych }\end{array}$ & 10,23 & 1,85 & 0,21 \\
\hline $\begin{array}{l}\text { Zajmowanie się czymś } \\
\text { innym }\end{array}$ & $\begin{array}{l}\text { zajmowanie się innymi } \\
\text { czynnościami, aby nie myśleć o } \\
\text { zdarzeniu }\end{array}$ & 1,19 & 2,21 & 0,56 \\
\hline Zaprzeczanie & $\begin{array}{l}\begin{array}{l}\text { odrzucanie } \\
\text { sytuacji }\end{array} \\
\end{array}$ & 3,8 & 0,5 & 0,44 \\
\hline Wyładowanie & ujawnienie negatywnych emocji & 9,21 & 0,35 & 0,97 \\
\hline $\begin{array}{l}\text { Zażywanie substancji } \\
\text { psychoaktywnych }\end{array}$ & $\begin{array}{l}\text { zażywanie środków dla } \\
\text { złagodzenia przykrych emocji }\end{array}$ & 4,11 & 0,28 & 0,11 \\
\hline Zaprzestanie działań & $\begin{array}{l}\text { rezygnacja z podejmowania } \\
\text { wysiłków dla osiągnięcia celu }\end{array}$ & 6,16 & 1,3 & 0,14 \\
\hline Obwinianie siebie & krytykowanie i obwinianie siebie & 13,26 & 1,94 & 0,12 \\
\hline
\end{tabular}

Wyniki te częściowo odpowiadają rezultatom uzyskanym przez Grabowskiego, Pollak i Czerw, którzy w swoich badaniach wskazują na grupowanie czynników w ramach stosowanych strategii radzenia sobie ze stresem. W badaniach tego zespołu, jak i w badaniach własnych zauważono skłonność badanych osób do stosowania działań z zakresu strategii zarówno emocjonalnej oraz strategii aktywnego działania [11]. 


\section{Wnioski}

W wyniku przeprowadzonych badań i uzyskanych na ich podstawie danych sformułowano następujące wnioski;

1. Pielęgniarstwo jest zawodem szczególnie obciążonym długotrwałym stresem, który przede wszystkim zależy od miejsca pracy i częstotliwości sytuacji stresowych. Pielęgniarki i pielęgniarze szczególnie doświadczają stresu w wyniku wykonywanych obowiązków zawodowych.

2. Pielęgniarstwo jako zawód jest obciążone występowaniem objawów depresji, które występują u ponad 1/3 badanych (34\%). Nasilenie tych objawów jest zależne od narażenia na stres w miejscu pracy i częstotliwości występowania stresorów.

3. Długość stażu pracy ma wpływ na częstość występowania objawów depresji. Największe nasilenie występowania epizodów depresyjnych o różnym nasileniu obserwuje się u połowy badanych pielęgniarek/pielęgniarzy o stażu pracy ponad 30 lat.

\section{Zalecenia dla praktyki pielęgniarskiej}

Pielęgniarki powinny systematycznie i długofalowo uczestniczyć w szkoleniach oraz kursach prowadzonych przez psychologów oraz terapeutów by doskonalić swoje umiejętności radzenia sobie w sytuacjach trudnych i stresowych.

\section{Bibliografia/Bibliography:}

1. Gross P. Czynniki wyzwalające stres w pracy pielęgniarki. Evereth News 11/2018. Evereth Publishing. Warszawa 2018.

2. Maharaj S., Lees T., Lal S. Prevalence and Risk Factors of Depression, Anxiety and Stress in a Cohort of Australian Nurses. International Journal of Enviromental Research and Public Health. Wydawnictwo MDPI. Bazylea 2018. 
3. Roberts RK, Grubb PL. The consequences of nursing stress and need for integrated solutions. Rehabilitation Nursing. The official journal of the Association of Rehabilitation Nurses 2014 nr 39. E-pub 2013:62-9.

4. Kędra E., Nowocień M. Czynniki stresogenne a ryzyko wypalenia zawodowego w pracy pielęgniarek. Pielęgniarstwo Polskie 2015;3(57):293-306.

5. Dąbrowska P., Olejnik B., Kułak - Bejda A., Krajewska-Kułak E. Narażenie na stres i wypalenie zawodowe w grupie pielęgniarek psychiatrycznych. Holistyczny wymiar medycyny. Wydawnictwo UM w Białymstoku. Białystok 2018. Tom IV: 530-536,557.

6. Maslach Ch., Leiter M. Prawda o wypaleniu zawodowym. Wydawnictwo Naukowe PWN. Warszawa 2011.

7. Kliszcz J. Depresja, lęk i pielęgniarskie życie. Magazyn pielęgniarki i położnej. Naczelna Izba Pielęgniarek i Położnych. Warszawa 2017:4-7.

8. Letvak S., Ruhm Ch., McCoy T. Depression in Hospital-Employed Nurses. Clinical Nurse Specialist. The Journal for Advanced Nursing Practice 2012;26/3:177 - 182. dostęp on-line $\mathrm{z}$ dnia 12.04.2020.

9. Gherardi-Donato EC, Cardoso L, Teixeira CA, Pereira Sde S, Reisdorfer E Association between depression and work stress in nursing professionals with technical education level. Revisto Latino Americana de Enfermagem. 2015; dostęp on-line z dnia 23.12.2019.

10. Haor B., Głowacka M., Ślusarz R., Piotrowska A. Behaviors and experiences of nurses connected with professional work. Nursing Problems / Problemy Pielęgniarstwa. Via Medica 2014:142-146.

11. Grabowski D., Pollak A., Czerw A. Wymiary etyki pracy jako predykatory strategii radzenia sobie ze stresem. Medycyna Pracy 2017;68(6):711724 dostęp on-line $\mathrm{z}$ dnia 02.04.2020. 
